\title{
Design of Artificial Neural Network based Maximum Power Point Tracking Considering Indore Region Data of 2019-2020
}

\author{
Prashansa Saxena $^{1^{*}}$, Navita Khatri ${ }^{2}$ \\ $I^{I^{*}}$ Student, M.Tech, Department of Electrical and Electronics Engineering, Shri Vaishnav Vidyapeeth Vishwavidyalaya, Indore, India \\ ${ }^{2}$ Faculty, Department of Electrical and Electronics Engineering, Shri Vaishnav Vidyapeeth Vishwavidyalaya, Indore, India
}

\begin{abstract}
The increasing consumption of energy and growth of environmental problems oil the wheels of exploring Renewable energy sources. Solar energy is one of the mostly used renewable energy and it is definitely a great solution as there are innovative ways to transfer energy using this technology. Efficient operation of solar panel is necessary due to higher cost. In this paper artificial neural network based MPPT algorithm is proposed for Indore region and comparison of Perturb and observe algorithm, Incremental conductance and ANN based MPPT is made using the temperature and irradiance data of 2019-2020 of Indore region, the study shows the Power Output and corresponding Voltage using different algorithms with the input as annual temperature and irradiance of Indore. The output is evaluated using Matlab version 2015. The study shows the effectiveness of artificial neural network as compared to other two algorithms.
\end{abstract}

Keywords: MPPT, ANN, $P \& O, \operatorname{InC}, \operatorname{Vmp}, \operatorname{Imp}$

\section{Introduction}

By 2007 only few techniques were available including Perturb and Observe method, fractional open circuit voltage, Incremental Conductance, curve fitting, fractional short circuit current, look up table etc that describes MPPT techniques. And because of these few techniques available for this particular field, Researchers always gets confused while choosing an MPPT technique for a particular application [1]. But now there are many new MPPT techniques including Adaptive Perturbation and Observation, Genetic Algorithm, Particle Swarm Optimization based MPPT, Fuzzy Logic and Artificial Neural Network is one of them that offers comparatively better response in each and every aspect [2]. Maximum Power point tracking (MPPT) is a technique used to get the maximum power which is mainly dependent on solar irradiance, temperature and total resistance.

The output power varies with cell voltage due to non-linear V-I characteristics so it's necessary to develop a technique which will track the available maximum power from sun [3]. Maximum power point is the point at which $\mathrm{dP} / \mathrm{dV}=0$ in the $\mathrm{P}-\mathrm{V}$ curve. It is also known as Knee-point. The V-I and P-V

*Corresponding Author: e-mail: vyasdd.diet@gmail.com,

Tel-+91-9827791934, +91-8770652406

ISSN 2320-7590

(C) 2021 Darshan Institute of Engg. \& Tech., All rights reserved characteristics are as follows:

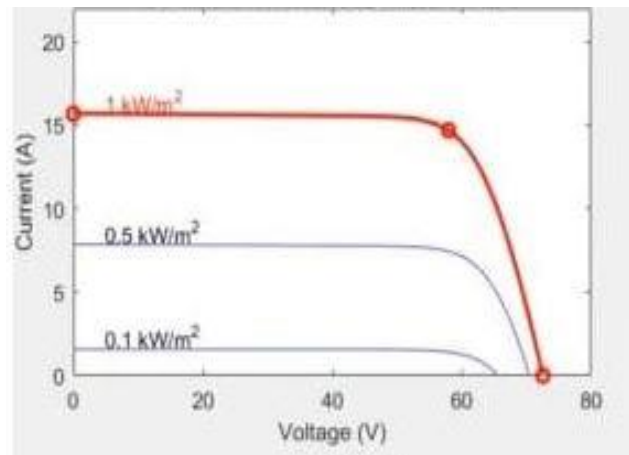

Figure 1(a). V-I Characteristic of solar cell

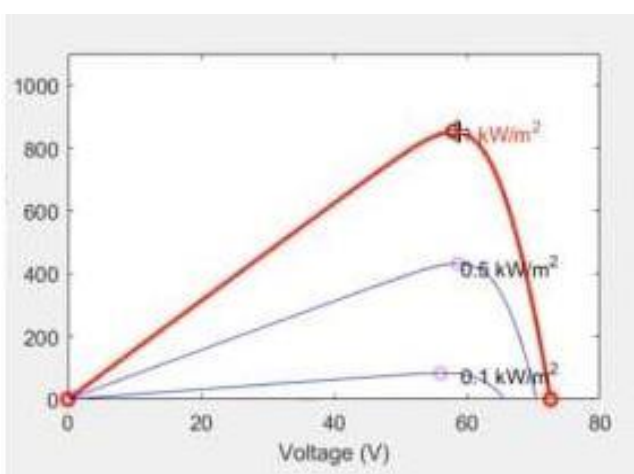

Figure 1(b). P-V Characteristic of solar cell 


\section{Maximum power point Tracking (MPPT) Algorithms}

There are various algorithms to track maximum power point but the problem considered by the MPPT algorithms is to automatically fetch the current Impp and Voltage Vmpp at which the PV array produce maximum power under a given irradiance and temperature [4]. The traditional Perturb and Observe method compares the current operation point and sequential perturbation point to examine the changes in the power and based on the difference obtained in the power, the controller increase or decrease the PV arrays output voltage [5]. The duty cycle of converter increases if the difference observed in the power is weighted positive and similarly the duty cycle of the converter must decrease if the difference observed in the power weighted negative. But if positive and negative weighted, error will occur and maximum power will not reach [6]. The Perturb and Observe method has a disadvantage that it only oscillates around the MPP

Another algorithm is Incremental Conductance which is a technique used in photovoltaic systems for its low cost, good performance and simplicity [7]. InC algorithm overcomes the disadvantage of $\mathrm{P} \& \mathrm{O}$ algorithm by determining when the MPPT reach the MPP and it can also track the rapid change in the irradiation more precisely than perturb and observe method. The only disadvantage of this method is the increased complexity [8].

Constant voltage algorithm assumes that, at different irradiance, maximum power point voltage is approximately equal which around $76 \%$ of Voc.

In recent years Artificial Neural Network acquire esteem in tracking maximum power point but it needs to be trained before being used in photovoltaic system [9-11]. It is a impressive technique for plotting the input-output non-linear function [12]. The major advantage this algorithm offers is that it doesn't need to solve the complex mathematical relation between solar temperatures; power output and total resistance and also the outputs are obtained with zero oscillations and in a very less time [13].

To operate the solar panel, Artificial neural network based Maximum power tracking (MPPT) using boost converter is used in this paper so that it can operate at constant voltage across the load for 2019-2020 data of Indore region and also compared the performance of classical and modern methods.

\section{Modelling of proposed system}

The proposed system is modeled and simulated in MATLAB 2015 version. The simulated model includes PV array model of $215 \mathrm{KW}$ model, dc-dc boost converter and MPPT based artificial neural network trained for real data of Indore region. Input to solar panel is irradiance $(\mathrm{G})$ and temperature $(\mathrm{T})$. The figure 2 shows basic schematic of proposed scheme.[14]

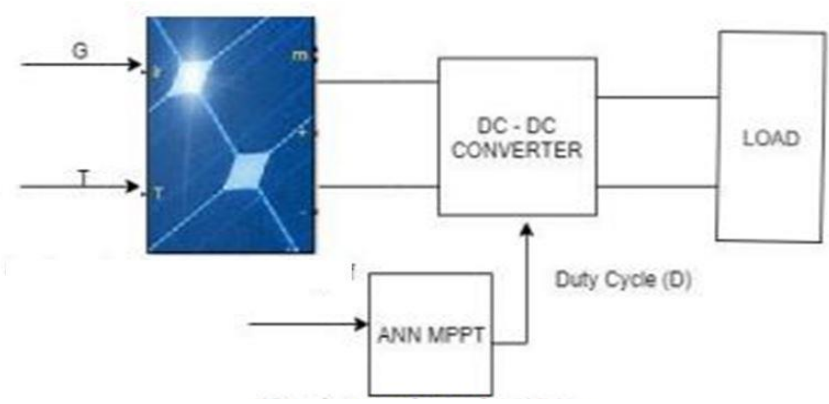

Figure 2. The schematic diagram of proposed system [6]

3.1 Solar Panel: The solar panel consists of arrays of PV cell connected in series and parallel. In this proposed system one array of Soltech 1STH-215-P is used. The peak power of this solar panel is $215 \mathrm{~W}$. The V-I and P-V characteristics at standard conditions (STC @ $25^{\circ} \mathrm{C}$ ) of the solar panel is shown in figure 3 . The table I shows the details of solar panel Voc, Isc, Vmp and Imp.

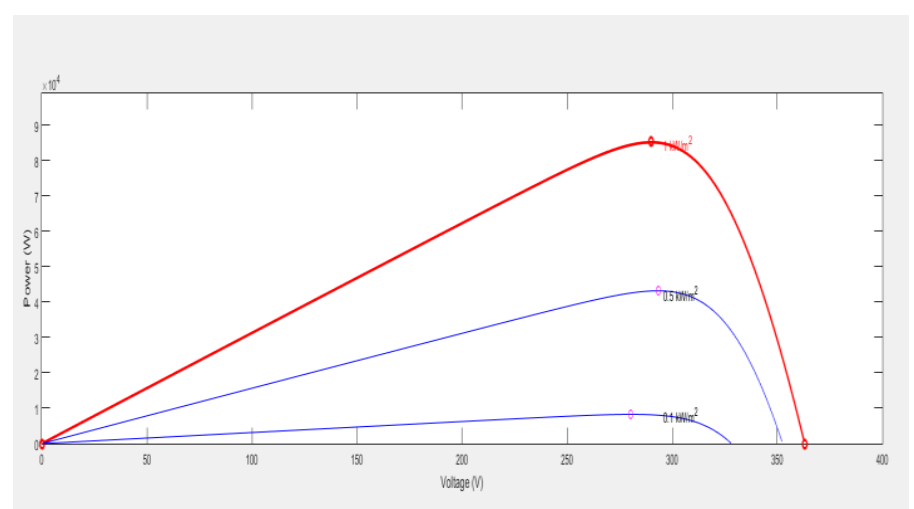

Figure 3(a). P-V Characteristic of Soltech 1STH-215-P

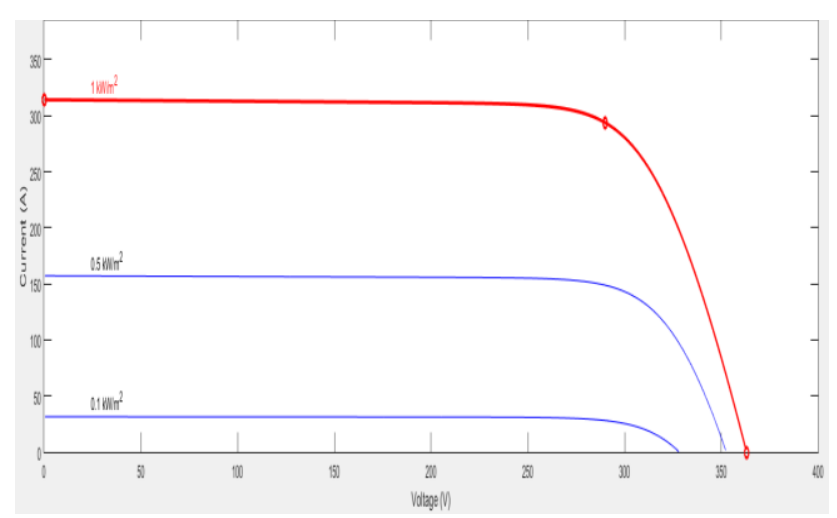

Figure 3(b). V-I Characteristic of Soltech 1STH-215-P

3.2 Artificial Neural Network (ANN): Artificial Neural Network is generally presented as systems of interconnected 'neurons' which communicates with each other by sending messages [15]. The connections are associated with weights that can be adjusted based on experience, making neural network capable of learning and adaptive to inputs [16]. The ANN model is performed using MATLAB/Simulink. A feed forward based neural network with two neurons in input 
layer, ten neurons in hidden layer and one in output layer is developed. The 'nnstart' tool is used to train the network and Levenberg-Marquardt algorithm is used whose neural network layout and training window is shown in Figure 4.

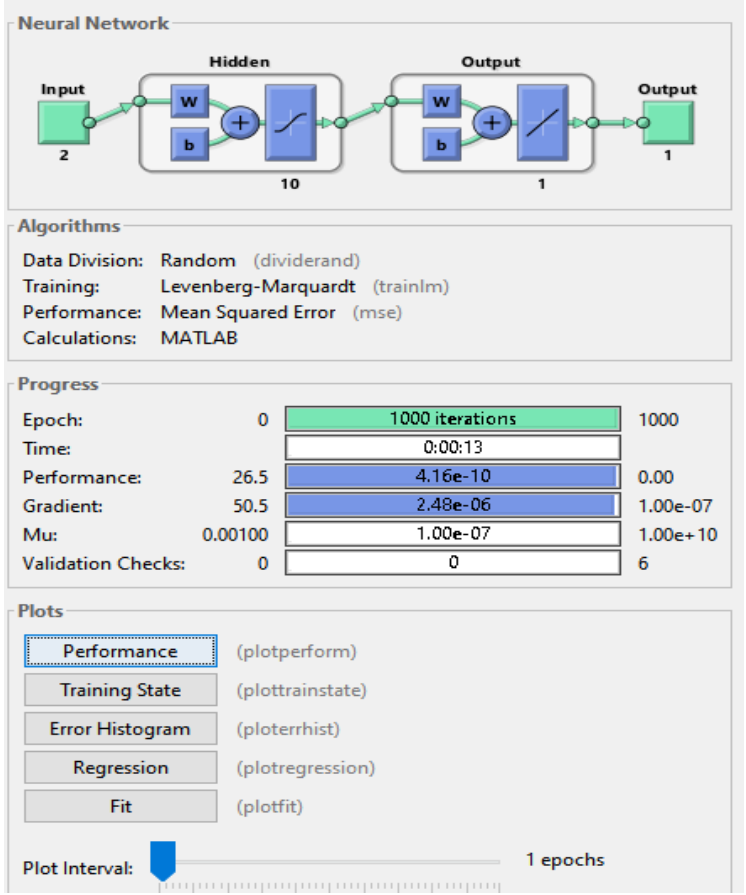

Figure 4. Neural network layout and its Training window

The input data for neural network is temperature and irradiance of Indore region (2019-2020) and based upon temperature and irradiation the network is going to provide voltage at maximum power point and maximum power at that point. In order to implement MPPT neural network algorithm, we need to collect data from PV array for training. During training the weights between two layers will be optimized or updated according to input and output data. LevenbergMarquardt algorithm is used in the proposed research work. The data for training the neural network is given below:

Table 1. Parameters of solar panel

\begin{tabular}{|l|l|}
\hline Parameters & Values \\
\hline Open Circuit Voltage (Voc) & $36.3 \mathrm{~V}$ \\
\hline Short Circuit Current (Isc) & $7.84 \mathrm{~A}$ \\
\hline Temperature coefficient of Voc & $-0.3699 \% / \mathrm{V}$ \\
\hline Temperature coefficient of Isc & $0.102 \% / \mathrm{A}$ \\
\hline Diode Saturation Current & $2.925 \mathrm{e}-10 \mathrm{~A}$ \\
\hline Light Generated Current & $7.864 \mathrm{~A}$ \\
\hline Diode Ideality factor & 0.98117 \\
\hline
\end{tabular}

\begin{tabular}{|l|l|}
\hline Shunt Resistance (Rsh) & $313.399 \mathrm{ohm}$ \\
\hline Series Resistance (Rs) & $0.3938 \mathrm{ohm}$ \\
\hline
\end{tabular}

The error and regression plot of neural network developed is shown in Figure 5(a) and (b) respectively.

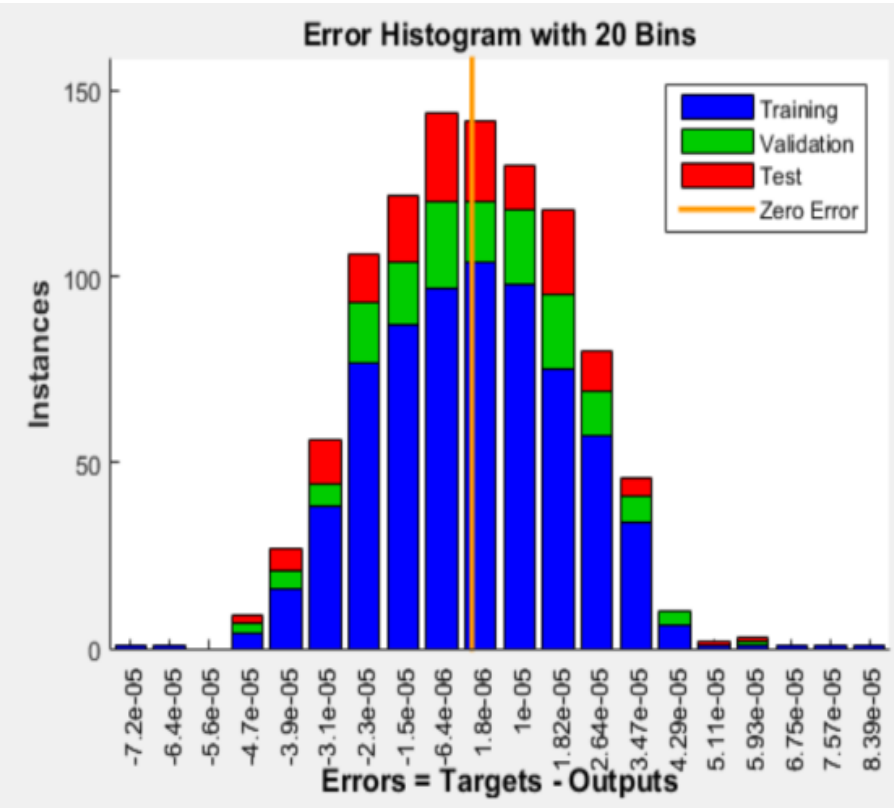

Figure 5(a). Error plot of Neural Network.
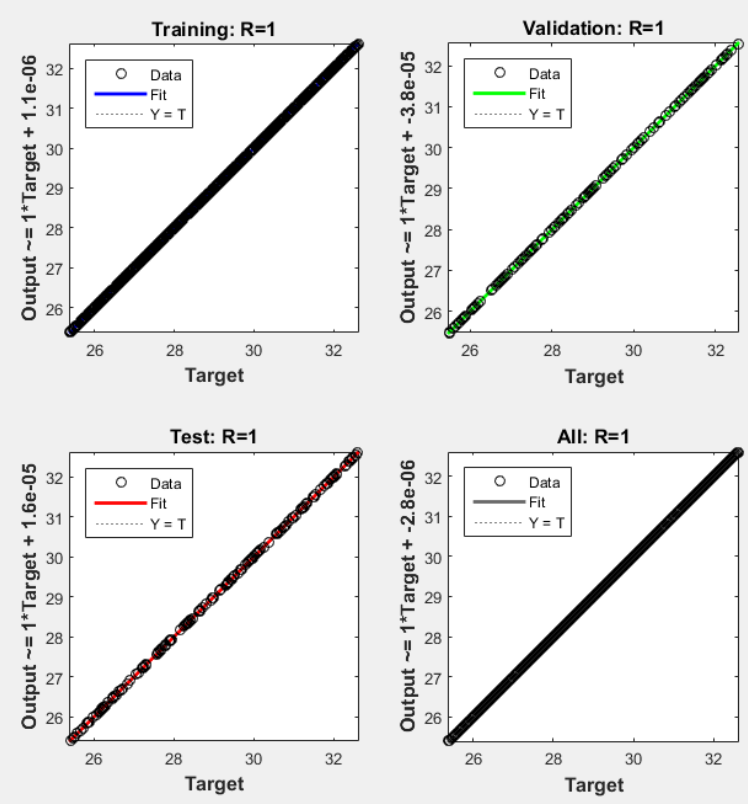

Figure 5(b). Regression plot of Neural Network.

3.3 Boost Converter: A boost converter is a DC to DC converter which is used to boost-up the DC voltage level. It is 
similar to a step-up chopper. The basic circuit diagram using IGBT is given below:

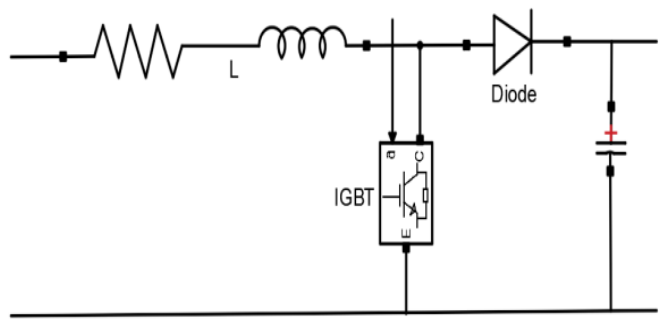

Figure 6. DC-DC boost converter

When IGBT is turned-on, current starts flowing through inductor and IGBT and energy gets deposited in the inductor and when IGBT is turned off then the energy earlier deposited in the inductor is released through the load and capacitor. Duty-ratio is responsible for the amount by which the output voltage gets boosted up.

For designing the boost converter in MATLAB/Simulink following values of the parameters are used as shown in Table 2:

Table 2. Boost converter input data

\begin{tabular}{|l|l|}
\hline Parameters & Values \\
\hline Input Voltage $\left(\mathrm{V}_{\text {in }}\right)$ & $55-58 \mathrm{~V}$ \\
\hline Output Voltage $\left(\mathrm{V}_{\mathrm{o}}\right)$ & $100 \mathrm{~V}$ \\
\hline Rated Power & 213.15 \\
\hline Switching Frequency $(\mathrm{fsw})$ & $5 \mathrm{KHz}$ \\
\hline Current Ripple $(\Delta \mathrm{I})$ & $5 \%$ \\
\hline Voltage Ripple $(\Delta \mathrm{V})$ & $1 \%$ \\
\hline
\end{tabular}

The formulas for calculating the parameters are given below: Input Current can be calculated as:

$\mathrm{I}_{\text {in }}=$ Rated Power/Input Voltage

Output Current can be calculated as:

$\mathrm{I}_{\text {out }}=$ Rated Power/Output voltage-

Inductance can be calculated as:

$\mathrm{L}=\mathrm{V}_{\text {in }} \times\left(\mathrm{V}_{\text {out }}-\mathrm{V}_{\text {in }}\right) /\left(\mathrm{f}_{\text {sw }} \times \Delta \mathrm{I} \times \mathrm{V}_{\text {out }}\right)$

Capacitance can be calculated as:

$\mathrm{C}=\mathrm{I}_{\text {out }} \times\left(\mathrm{V}_{\text {out }}-\mathrm{V}_{\text {in }}\right) /\left(\mathrm{f}_{\text {sw }} \times \Delta \mathrm{V} \times \mathrm{V}_{\text {out }}\right)$

\section{Results and discussion}

In this section result of various simulation studies of incremental conductance, perturb and observe, and proposed ANN MPPT algorithm for $215 \mathrm{~W}$ PV array are presented considering solar irradiance and temperature data set of Indore region (2019-2020). The three MPPT algorithms are simulated in one Simulink model and similar parameters are set to compare the results. The proposed Simulink model is shown in figure.7. The entire three MPPT algorithms have two inputs (temperature and irradiance) and one output i.e reference output voltage corresponding to maximum point in the PV characteristics. The output of the MPPT algorithm is used for generation of duty cycle for boost converter. The duty cycle for the system is calculated using the reference voltage $\left(\mathrm{V}_{\text {ref }}\right)$. The duty cycle is calculated using equation 5 :

$\mathrm{D}=1-(\mathrm{Vin} / \mathrm{Vo})$

where Vin is instantaneous operating voltage at PV panel Vo is the reference voltage generated from MPPT algorithm.

The Simulink model of incremental conductance (InC), Perturb and Observe (P\&O) and ANN-MPPT, methods are shown in figure 8-10 respectively. The maximum power and voltage at maximum point are evaluated through the Simulink model by giving input as average monthly irradiance and temperature of Indore region. The data of Irradiance of Indore region for 2019-2020 is referred from National Renewable Energy Laboratory (NREL) [17]. These simulation results are compared to Perturb and observe, Incremental conductance and artificial neural network based maximum power point tracking and shown in table III and IV.

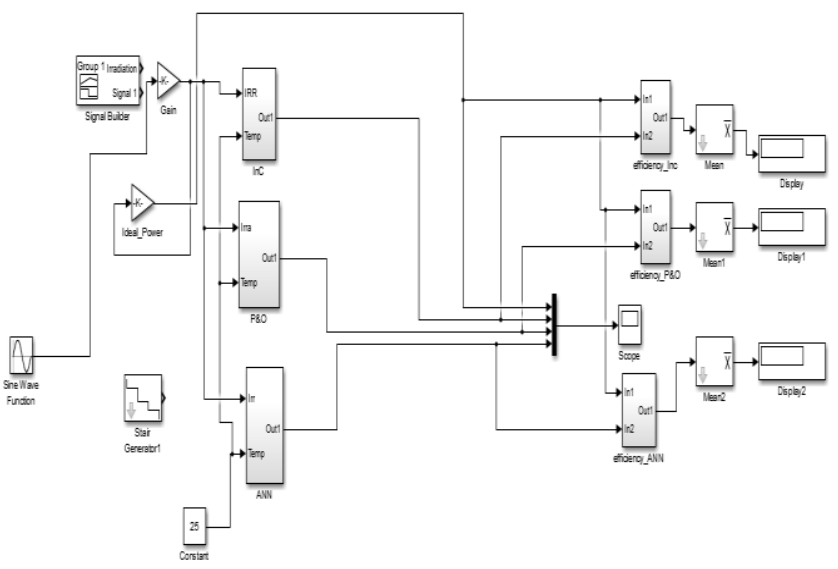

Figure 7. Simulink model of the proposed system

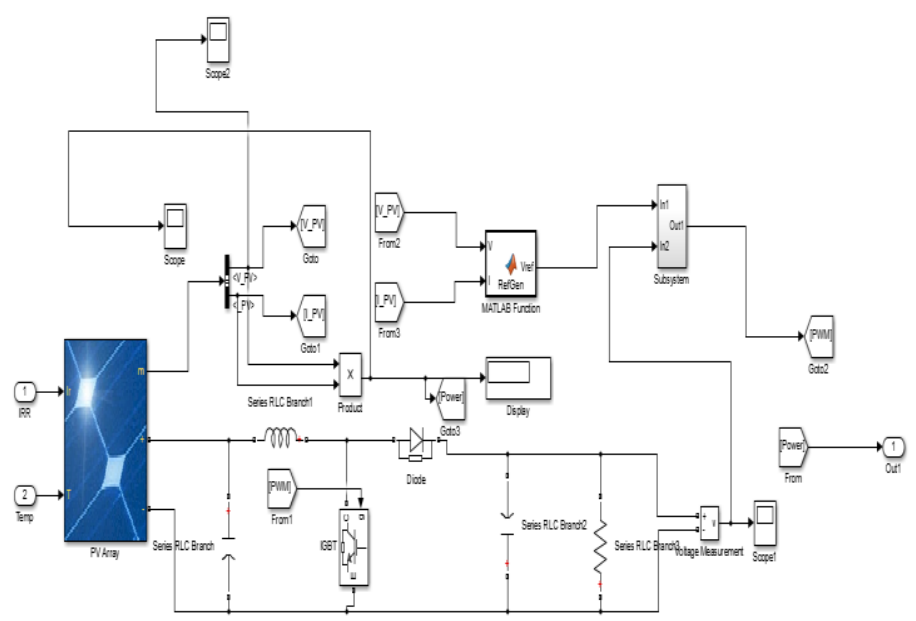

Figure 8. Subsystem of incremental conductance 


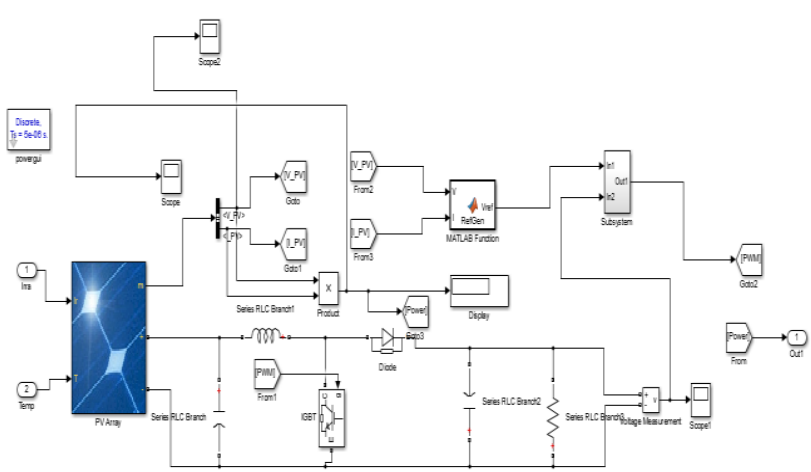

Figure 9. Subsystem of Perturb and observe algorithm

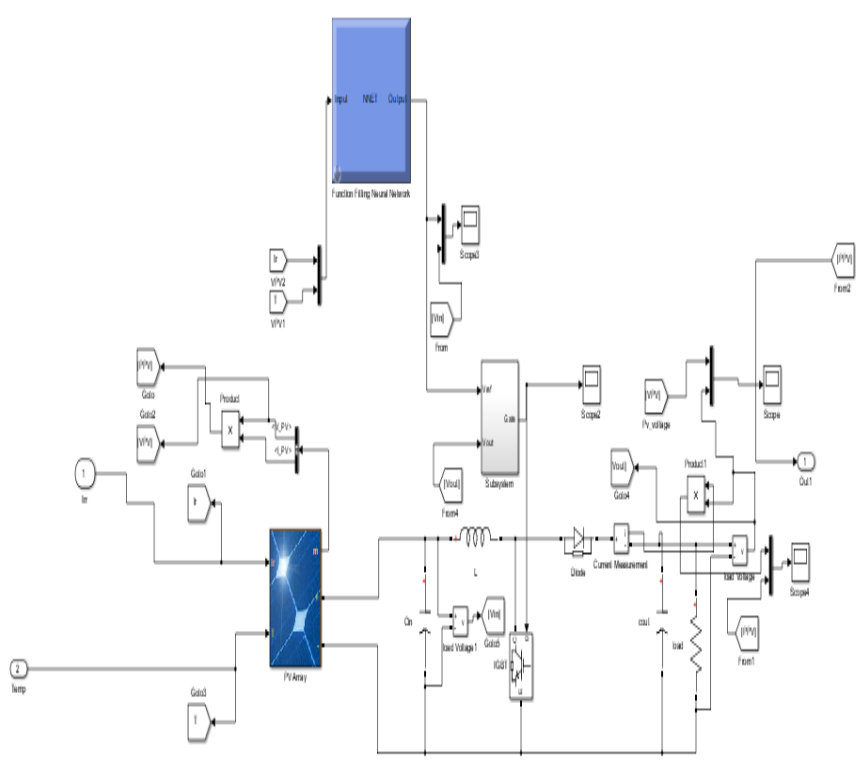

Figure 10. Subsystem of ANN-MPPT algorithm

This can be observed from the both the tables that maximum power output of ANN-MPPT algorithm is much better compared to the InC and $\mathrm{P} \& \mathrm{O}$ method. This can be interpreted that steady state performance of ANN-MPPT is much better than $\mathrm{InC}$ and $\mathrm{P} \& \mathrm{O}$ method. Hence it is clear that the artificial neural network algorithm outperforms the other two algorithms.

The results are also evaluated under the fast changes in irradiance and temperature kept at $25^{\circ} \mathrm{C}$. The performance of all the three methods is evaluated by providing sine wave pattern input in which irradiance is changing from 0 to 1000 $\mathrm{kw} / \mathrm{m}^{2}$ and again 1000 to $0 \mathrm{kw} / \mathrm{m}^{2}$. The figure. 11 shows the comparative results of maximum power between three algorithms. This can be easily distinguished that ANN is able track MPPT point fast and accurately as compared to the other two algorithms. The ANN can be able to track the MPPT point within $0.1 \mathrm{sec}$ whereas $\mathrm{InC}$ and $\mathrm{P} \& \mathrm{O}$ algorithms took $5.8 \mathrm{sec}$ to track the maximum power. Hence it can be observed from the results that ANN had better performance over other two algorithms both in steady and transient states.
Table 3. Maximum power steady state values for average monthly temperature and irradiance of InC, $\mathrm{P} \& \mathrm{O}$ and $\mathrm{ANN}$ MPPT algorithms

\begin{tabular}{|c|c|c|c|c|c|}
\hline Month & $\begin{array}{l}\text { Average } \\
\text { Monthly } \\
\text { Temp. }\end{array}$ & $\begin{array}{l}\text { Average } \\
\text { Monthly } \\
\text { Irradiance }\end{array}$ & $\begin{array}{l}\text { InC } \\
\text { O/p } \\
\text { Power }\end{array}$ & $\begin{array}{l}\text { P\&O } \\
\text { O/p } \\
\text { Power }\end{array}$ & $\begin{array}{l}\text { ANN } \\
\text { O/p } \\
\text { Power }\end{array}$ \\
\hline Jan & 27.5 & 560 & 121.4 & 116.3 & 154.1 \\
\hline Feb & 32 & 620 & 130.7 & 123.2 & 194.5 \\
\hline Mar & 36.5 & 654 & 119.5 & 134.1 & 192.5 \\
\hline Apr & 39.5 & 720 & 143.4 & 143.4 & 194.4 \\
\hline May & 38.3 & 700 & 141.8 & 141.4 & 194.5 \\
\hline Jun & 33.2 & 598 & 118.8 & 118.8 & 189.6 \\
\hline July & 29 & 450 & 87.59 & 89.08 & 123.9 \\
\hline Aug & 29.7 & 470 & 80.16 & 80.16 & 138.8 \\
\hline Sept & 31 & 580 & 114 & 114 & 151.3 \\
\hline Oct & 30.2 & 550 & 105.1 & 110.2 & 133.5 \\
\hline Nov & 27.3 & 554 & 113.7 & 113.7 & 143.5 \\
\hline Dec & 26 & 523 & 96.51 & 103.1 & 150.6 \\
\hline
\end{tabular}

Table 4. Operating voltage at maximum power for average monthly temperature and irradiance of InC, $\mathrm{P} \& \mathrm{O}$ and $\mathrm{ANN}$ MPPT algorithms

\begin{tabular}{|c|c|c|c|l|l|}
\hline Month & $\begin{array}{l}\text { Average } \\
\text { Monthly } \\
\text { Temp. }\end{array}$ & $\begin{array}{l}\text { Average } \\
\text { Monthly } \\
\text { Irradiance }\end{array}$ & $\begin{array}{l}\text { InC } \\
\text { O/p } \\
\text { Volt. }\end{array}$ & $\begin{array}{l}\text { P\&O } \\
\text { O/p } \\
\text { Volt. }\end{array}$ & $\begin{array}{l}\text { ANN } \\
\text { O/p } \\
\text { Volt. }\end{array}$ \\
\hline Jan & 27.5 & 560 & 29.38 & 29.75 & 31.62 \\
\hline Feb & 32 & 620 & 27.83 & 29.72 & 30.36 \\
\hline Mar & 36.5 & 654 & 30.26 & 28.21 & 30.21 \\
\hline Apr & 39.5 & 720 & 28.38 & 28.38 & 30.35 \\
\hline May & 38.3 & 700 & 28.22 & 28.21 & 30.35 \\
\hline Jun & 33.2 & 598 & 25.64 & 25.64 & 29.99 \\
\hline July & 29 & 450 & 25.06 & 25.57 & 30.44 \\
\hline Aug & 29.7 & 470 & 31.78 & 31.78 & 29.9 \\
\hline Sept & 31 & 580 & 30.11 & 30.11 & 31.18 \\
\hline Oct & 30.2 & 550 & 31.22 & 25.96 & 31.44 \\
\hline Nov & 27.3 & 554 & 26.82 & 26.82 & 31.66 \\
\hline Dec & 26 & 523 & 31.73 & 25.44 & 31.12 \\
\hline
\end{tabular}

From the presented results it can be interpreted that varying temperature and irradiations and fast changing irradiance, artificial neural network based maximum power point tracking method can efficiently track the maximum power point as compared to other two algorithms. 


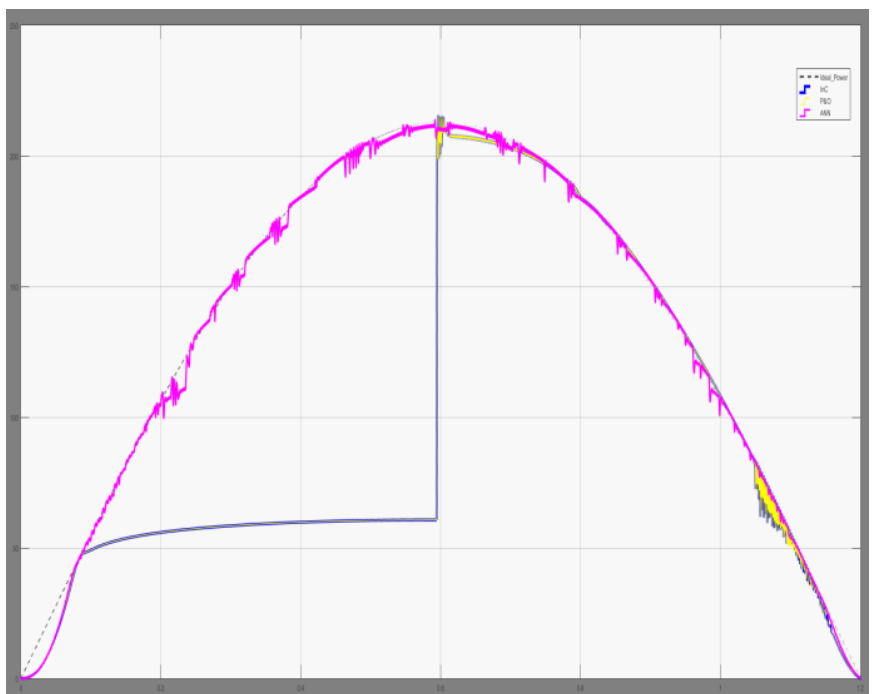

Figure 11. Output of InC, $\mathrm{P} \& \mathrm{O}$ and ANN MPPT algorithm with fast varying irradiance.

\section{Conclusion}

As the solar energy source is assumed to be infinite, solar photovoltaic based electricity generation continues to grow. The only obstacle of such PV based solar systems are poor conversion efficiency, MPPT is the technique used to extract maximum output power from PV array at different irradiations. But it also has issue of delivering maximum efficiency, so this paper presented a proposed research work of implementation of artificial neural network with maximum power point tracking and it is concluded that artificial neural network based maximum power point tracking algorithm is more efficient than perturb and observe algorithm and incremental conductance algorithm in tracking the maximum power point as shown from the tables and output of efficiency comparison model. Also it holds less number of oscillations, the controller is fast and comparatively accurate in nature and more robust. In this paper 12 data sets i.e. temperature and irradiance of Indore region (2019-2020) is used but if large number of datasets is used to train the network then also the artificial neural network based maximum power point tracking algorithm proved to be more efficient. The artificial neural network tracks the exact maximum power point whereas other two algorithm hover around that point. The limitation of the proposed work is that it is only restricted to Indore region as the input is the temperature and irradiance of Indore region but the technique can be used to calculate the maximum power and corresponding voltage for any region by considering temperature and irradiance of that particular region.

\section{Nomenclature}

MPPT- Maximum Power Point Tracking

ANN-Artificial Neural Network

P\&O- Perturb and Observe

InC- Incremental Conductance
Vmp- Voltage at maximum power

Imp- Current at maximum power

IGBT- Insulated gate bipolar transistor

PV- Photovoltaic

$\mathrm{Kw} / \mathrm{m}^{2}$ - Kilo Watt per meter square

\section{References}

1. Baimel, D.; Tapuchi, S.; Levron, Y.; Belikov, J. "Improved Fractional Open Circuit Voltage MPPT Methods for PV Systems", Electronics 2019, 8, 321. https://doi.org/10.3390/electronics 8030321

2. C. Larbes.; S.M. Ait Cheikh.; T. Obeidi,; A. Zerguerras. "Genetic algorithms optimized fuzzy logic control for the maximum power point tracking in photovoltaic system", Renewable Energy, Volume 34, Issue 10,2009,20932100,ISSN

0960-

1481,https://doi.org/10.1016/j.renene.2009.01.006

3. Dalila Beriber.; Abdelaziz Talha "MPPT Techniques for PV Systems", 4th International Conference on Power Engineering, Energy and Electrical Drives, Istanbul, Turkey, 2013, pp. 1437-1442, doi: 10.1109/PowerEng.2013.6635826

4. Nedumgatt, J. J., Jayakrishnan, K. B., Umashankar, S., Vijayakumar, D., \& Kothari, D. P. (2011). "Perturb and observe MPPT algorithm for solar PV systems-modeling and simulation". 2011 Annual IEEE India Conference. https://doi:10.1109/indcon.2011.6139513

5. Salman S.; AI, X. \& WU, Z.; "Design of a P-\&-O algorithm based MPPT Charge Controller for a Standalone 200 Watt PV System", Publisher- Springer open 2018, Received- 01 July 2017, Published- 17 August 2018, https://doi.org/10.1186/s41601-018-0099-8

6. Ali M. Eltamaly, Almoataz Y. Abdelaziz Editor "Modern Maximum Power Tracking Techniques for Photovoltaic Energy Systems", Springer International Publishing, ISBN: 978-3-030-05578-3 (eBook), Edition $1,2019$.

7. Dhaouadi, G., Djamel, O., Youcef, S., \& Salah, C. (2019). "Implementation of Incremental Conductance Based MPPT Algorithm for Photovoltaic System”. 2019 4th International Conference on Power Electronics and Their (ICPEA). doi:10.1109/icpea1.2019.8911186

Applications

8. Mathur, D., "Maximum Power Point Tracking with Artificial Neural Network" International Journal of Emerging Science and Engineering (IJESE),Volume2, Issue-3, January 2014.

9. Samangkool, K.;Premrudeepreechacham. S; "Maximum power point tracking using neural networks for gridconnected photovoltaic system," Future Power Systems, vol., no., pp.4 pp.-4, 18-18 Nov. 2005

10. M. Veerachary, T. Senjyu and K. Uezato, "Neuralnetwork-based maximum-power-point tracking of coupled-inductor interleaved boost converter-supplied 
PV system using fuzzy controller," IEEE Trans. Ind. Electron., vol. 50, no. 4, pp. 749-758, Aug. 2003. 11.

11. Syafaruddin, E. Karatepe and T. Hiyama, "Artificial neural networkpolar coordinated fuzzy controller based maximum power point tracking control under partially shaded conditions," IET Renewable Power Generation, vol. 3, no. 2, pp. 239-253, June 2009.

12. Mohammed Sherif, Srivas Seshadri. "Artificial Neural Network based MPPT of Solar Photovoltaic cells", International Journal of Innovative Research in Science, Engineering and Technology, Vol. 7, Issue 5, May 2018

13. Duwadi, Kapil. (2015). "Design of ANN based MPPT for Solar Panel." 10.13140/RG.2.1.3687.7925.
14. S.R. Revathy, V. Kirubakaran,"A Critical Review of Artificial Neural Networks Based Maximum Power Point Tracking Techniques", Journal of Critical Reviews, Vol 7, Issue 12, 2020

15. F. Sedaghati, A. Nahavandi, M. A. Badamchizadeh, S. Ghaemi, and M. Abedinpour Fallah, "PV maximum power-point tracking by using artificial neural network," Mathematical Problems in Engineering, vol. 2012, Article ID 506709, 10 pages, 2012 https://doi.org/10.1155/2012/506709

16. Wen $\mathrm{Yu}$, Haibo He "Advances in Neural Networks", Edition 6th, Springer 2009

17. https://www.nrel.gov/gis/solar.html 